\title{
Modeling of the Factors Affecting e-Commerce Use in Turkey by Categorical Data Analysis

\author{
Factors Affecting e-Commerce Use
}

\author{
Ömer Alkan ${ }^{1}$ \\ Associate Professor \\ Department of Econometrics \\ Ataturk University, Erzurum, Turkey
}

\author{
Hasan Küçükoğlu ${ }^{2}$ \\ PhD Candidate, Department of \\ Management Information Systems \\ Ataturk University, Erzurum, Turkey
}

\author{
Gökhan Tutar ${ }^{3}$ \\ Lecturer, Department of \\ Management Information Systems \\ Ataturk University, Erzurum, Turkey
}

\begin{abstract}
Commerce use is a subject of study that has been frequently discussed in recent years. The aim of this study was to detect the socio-demographic and economic factors affecting ecommerce use of individuals in Turkey. The micro dataset obtained from Information and Communication Technology (ICT) Usage Survey in Households performed by the Turkish Statistical Institute in 2014-2018 was employed in this study. Multinomial logistic and multinomial probit regression analyses were performed to detect the factors affecting e-commerce use of individuals in Turkey. The data of 129,643 individuals, who participated in ICT Usage Survey in Households in 2014-2018, were employed in the regression analyses. According to the analysis results, the variables of survey year, age, gender, educational level, occupation, income level, region and household size were detected to be effective on online shopping. The results of the study indicated that e-commerce use was gradually increasing. It was determined that more educated and young individuals and individuals living in relatively more developed regions were more inclined to online shopping. Policies should also be developed to increase e-commerce use of low educated individuals and individuals over middle age. In particular, small and medium-sized businesses (SMB) should pay more attention to the use of e-commerce in order to increase their activities by taking these situations into consideration. Indeed, how important e-commerce use is has been found out in epidemics/pandemics such as COVID-19, which causes people to lock themselves at home in the countries.
\end{abstract}

Keywords-Electronic commerce; online shopping; online purchase; e-commerce; Turkey; multinomial probit regression

\section{INTRODUCTION}

Various shopping techniques and methods have been employed according to needs throughout history. Nowadays, the final point these changes have reached is online shopping [1]. It is possible to say that today's technologies and the innovations brought by them have strong effects on this process of change. Along with the fact that information and internet technologies have become a part of life, individuals' motivations for online shopping are affected by this development [2].

In particular, the start of internet use has revolutionized commercial activities by enabling the shopping activities over the network called e-commerce [3]. e-Commerce use refers to shopping behaviors of consumers in an online store or on a website used for online purchasing [4]. Global shoppers get tremendous benefits from purchasing products and services online. Internet allows product and service availability at minimum cost for $7 / 24$ and 365 days [5]. Online shopping is one of the commonly used environments for easy shopping. Actually, it is a popular tool for shopping in the internet community in many parts of the world [6]. Through online shopping, detailed information and multiple options are also offered to customers so that they can compare the products and prices. With this diversity, it also becomes easier to find the products needed. Due to these opportunities, online shopping is becoming popular and the number of people who prefer this method is increasing day by day [7].

This method, which is beneficial for the companies that provide services over the network in addition to the advantages it offers to the consumer, reduces the transaction costs and provides companies with more global access [8]. Especially with the widespread use of the internet, consumers have the opportunity to access the product they desire at any time and from any location without being limited to any geographical region. Consumers can make choices for the product they will buy by making comparisons among more options. e-Commerce also offers advantages such as ease of use, time and energy savings. In the studies, it was observed that online shopping provided more satisfaction for the consumers looking for both comfort and speed [7]. e-Commerce is taking the place of traditional shopping methods and will become even more popular in the near future [9]. The demands for online shopping have increased so much that not only big companies but also small businesses and individuals sell handmade products over the Internet [10]. Online shopping is a new form of business, and this form of business supports the economic growth of underdeveloped regions [11].

As the contribution of online shopping to the economy has increased, the competition regarding this issue has also increased. Since online shopping has some advantages compared to traditional businesses, businesses are heading towards online shopping [12]. It is observed that there has been a great increase in both quantity and volume in individuals' online shopping through smart devices, such as mobile phones, personal digital assistants (PDAs), computers, and tablets, both in the world and in our country, especially in recent times [13]. Along with the continuous growth of global trade and the rapid advancement of digital society, consumers are increasingly heading towards shopping from abroad [14]. These tendencies 
have promoted the increase of traditional foreign trade patterns at various dimensions of sustainability. Through competitive prices and a wide range of products, charming products can be offered to consumers and the time and space distance between consumers and suppliers can be shortened considerably [15]. Consumers use the internet to search for information about products, and they are expected to increase it in the future [16]. Unlike traditional shopping, online shopping has lower search costs because it reduces the time consumers spend on finding products and reduces the loss of energy to compare. Therefore, online shopping helps consumers to get price and product information from various sellers more quickly and easily [17].

Information seeking is a stage of the decision making process in which individuals actively collect information from both internal and external sources and include it before making a choice. Individuals adopt this behavior to meet their need for information [18]. Before purchasing products or services, consumers search and collect the relevant information and then compare the sellers based on this information to make the best purchasing decision [19]. Consumers are currently using the Internet to search for information and are expected to increase it in the future [16].

It is not surprising that the number of online shoppers has increased a lot over the past few years along with the increase in number of internet users. A global study on the trends in online shopping conducted by The Nielsen Company reveals that over $85 \%$ of internet users in the world perform a purchasing transaction over the internet. Online shopping is directly proportional to the increasing use of the internet. A study on world internet usage and population statistics in 2009 reveals that $26.6 \%$ of the total world population were internet users and there has been a growth rate of $399.3 \%$ over the past decade. While 230-billion dollar transactions were performed in cross-border online shopping from consumer to consumer all around the world in 2015, this figure is expected to increase to 1 trillion dollars a year in the near future [20]. In a comprehensive study on internet use and online shopping on a global scale, it was determined that the number of internet users increased from 5.233 billion to 5.530 billion in the last 5 years, that the number of people who had accessed the Internet at least once increased from $48.2 \%$ to $59.9 \%$ compared to the population, and that these people usually preferred desktop computers by $41 \%$, mobile phones by $40 \%$, tablets by $3 \%$ and other devices by $16 \%$ to use the internet. In terms of frequency of shopping, it was reported that while $31 \%$ of internet consumers around the world performed online shopping once a month, $24 \%$ of them performed online shopping every other week, $20 \%$ of them performed online shopping once a week, $15 \%$ of them performed online shopping 3-4 times in 3 months, and $10 \%$ of them performed online shopping every 3 months. On the basis of transaction volume, the volume of e-commerce, which was 1.3 trillion dollars in 2014, reached 3.5 trillion dollars in 2019 , and it is predicted to increase to 4.9 trillion dollars in 2021 [21].

Although traditional shopping methods are still employed around the world, it is observed that online shopping transactions have increased rapidly. According to the Global eCommerce Report, two shopping categories in which consumers do more online shopping compared to stores are book, music, movie \& video games (60\%) and toys (39\%) shopping. In general, while $43 \%$ of purchases in the electronics $\&$ computer category were made over the internet, $36 \%$ of purchases in the sport equipment \& outdoor category, $37 \%$ of purchases in the health \& beauty category, $40 \%$ of purchases in the clothing \& footwear category, $32 \%$ of purchases in the jewelry/watches category, $33 \%$ of purchases in the household appliances category, $30 \%$ of purchases in the DIY/home improvement category, $30 \%$ of purchases in the furniture \& homeware category, and $23 \%$ of purchases in the grocery category were made over the internet. In the same report, when the sectors in which purchases are made over the internet were analyzed on the basis of continents, it was reported that while the people in the Asia-Pacific region mostly (40\%) purchased packaged foods, purchases were mostly made in the video games sector (31\%) in North America, personal care sector in (28\%) in South America, fashion sector (49\%) in Eastern Europe, electronic appliances sector (36\%) in Western Europe, and fashion sector (35\%) in the Middle East and Africa [21].

In a study covering 28 countries including European countries and Turkey, the average internet usage of people who had ordered or purchased a product or service over the internet in the past year was calculated to be $87 \%$ in Europe and $72 \%$ in Turkey, and the average of people who had ordered or purchased a product or service was calculated to be $60 \%$ in Europe and $25 \%$ in Turkey [22].

Different dimensions were also discussed in the studies on e-commerce use. In a study investigating the determining factors in online shopping, it was indicated that the quality of the website over which services are provided had positive effects on consumers' satisfaction and loyalty behaviors [23]. In another study, online shoppers were evaluated in terms of five different shopping motivations such as convenience, searching brands, information search, shopping experience and social interaction [24]. In another study, it was determined that website design, convenience, information usability, payment system and security had significant positive effects on shopping motivations [25]. It is also emphasized that the price is an important shopping motivation that affects the purchase intention [26,27]. It is indicated that wide product availability and price comparison between similar products have led customers to online shopping [28]. In another study in which the factors affecting consumers' online shopping were analyzed, the variables of perceived value, ease of use, satisfaction, reliability of the website, secure payment, customization and interaction were observed to have quite directive effects on consumers [29]. In an empirical study in which individuals' purchasing behaviors for online shopping were investigated, it was concluded that internet access, website aesthetics, security, user experience, age and learning capacity were very important factors in exhibiting such behaviors [30]. In another recent study conducted on online purchasing preferences of university students in India, it was determined that the presence of too many options for the product intended to be purchased increased purchasing anxiety in consumers. Furthermore, it was indicated that consumers' characteristics, contextual factors, and perceived uncertainty had negative effects on their online purchasing preferences, and that the reliability of the website also had negative effects 
on purchasing preferences [31]. The results of a study conducted in Thailand revealed that the perceived benefit had no significant effect on consumers' shopping over the internet, however, perceived ease of use, perceived security, perceived uncertainty, and online shopping experience played an effective role in online shopping [13].

Individual differences as well as technological developments are also effective on e-commerce use. To know the products purchased according to individual characteristics can be employed to detect the advertisements that will be provided to be viewed by individuals with certain characteristics, especially in social media. The aim of this study was to detect the socio-economic and demographic factors affecting online shopping of individuals in Turkey. In this study, multinomial logistic and multinomial probit regression analyses were employed to detect the factors affecting e-commerce use of individuals.

\section{MATERIALS AND Methods}

\section{A. Data}

The micro dataset obtained from Information and Communication Technology (ICT) Usage Survey in Households performed by the Turkish Statistical Institute in 2014-2018 was employed in this study. In this study, the data of 129,643 individuals, who participated in ICT Usage Survey in Households in 2014-2018, were employed.

The aim of the ICT Usage Survey in Households is to detect the criteria of information society and to produce the relevant statistics. The scope of the study is households in all settlements located within the borders of Turkey. Those in school, dormitory, hotel, kindergarten, nursing home, hospital and prison, which are defined as institutional population, and those residing in barracks and military houses were not included. Furthermore, settlements, the population of which would not exceed $1 \%$ of the total population where it was considered that sufficient number of sample households (small villages, nomad groups, fields, etc.), could not be reached, were excluded. Individuals between the ages of 16 and 74 years were included according to the methodology of the research. A stratified two stage cluster sampling method was employed obtain the data. The first stage sampling unit was the blocks that were randomly selected proportionally to their size from among the clusters (blocks) containing an average of 100 household addresses, and the second stage sampling unit was the household addresses systematically randomly selected from each selected cluster [32].

\section{B. Measures}

The dependent variable of the study was e-commerce use measured by the question "When was the last time you purchased or ordered goods/services for personal use over the Internet (websites or mobile applications)?" (In the past three months; more than three months; more than a year; never used). The categories "more than three months" and "more than a year" were combined and a three-category dependent variable was generated in order to obtain more significant results.
The independent variables in the study were detected by performing a comprehensive literature review. Sociodemographic and economic factors that could be effective on ecommerce use were considered as independent variables. Independent variables were year of survey, age, gender, educational level, occupation, income level, and household size.

One of the independent variables was the region variable. The establishment of Nomenclature of Territorial Units for Statistics (NUTS) in Turkey is based on the necessity to establish Development Agencies. The national program prepared after the accession partnership agreement signed with the EU has made it necessary to establish NUTS regions, as they see NUTS regions as a prerequisite for the establishment of Development Agencies. The existing geographical regions were not taken into account in the establishment of NUTS regions in Turkey, and regional boundaries were detected depending on many different criteria. The most important of them is the amount of population. Except for the population, cultural structure and development status of the provinces were also taken into consideration [33]. Turkey was divided into 12 regions at Level 1 under the name of Nomenclature of Territorial Units for Statistics. Some regions were combined and expressed in 8 regions to obtain more significant results in the analysis [34]. These regions and the provinces in these regions are presented in Table I in detail.

\section{Research Method}

Survey statistics in Stata 15 (Stata Corporation) were used to account for the complex sampling design and weights. Weighted analysis was performed [35]. The frequency and percentages were first obtained according to the status of ecommerce use of the individuals who participated in the study. Chi-square test of independence was performed to examine the relationship between the status of e-commerce use and the independent variables. Then, the factors affecting e-commerce use were detected using the multinomial logistic regression and multinomial probit regression analyses.

TABLE I. STATISTICAL REGION UNITS CLASSIFICATION -LEVEL 1

\begin{tabular}{|l|l|l|}
\hline Code & Level 1 & Provinces \\
\hline TR1 & İstanbul & İstanbul \\
\hline $\begin{array}{l}\text { TR2/ } \\
\text { TR4 }\end{array}$ & $\begin{array}{l}\text { West Marmara/ } \\
\text { East Marmara }\end{array}$ & $\begin{array}{l}\text { Tekirdağ, Edirne, Kırklareli, Balıkesir, } \\
\text { Çanakkale, Bursa, Eskişehir, Bilecik, } \\
\text { Kocaeli, Sakarya, Düzce, Bolu, Yalova }\end{array}$ \\
\hline TR3 & Aegean & $\begin{array}{l}\text { İzmir, Aydın, Denizli, Muğla, Manisa, } \\
\text { Afyonkarahisar, Kütahya, Uşak }\end{array}$ \\
\hline $\begin{array}{l}\text { TR5/ } \\
\text { TR7 }\end{array}$ & $\begin{array}{l}\text { Western Anatolia/ } \\
\text { Central Anatolia }\end{array}$ & $\begin{array}{l}\text { Ankara, Konya, Karaman, Krrıkale, } \\
\text { Aksaray, Niğde, Nevşehir, Kırşehir, Kayseri, } \\
\text { Sivas, Yozgat }\end{array}$ \\
\hline TR6 & Mediterranean & $\begin{array}{l}\text { Antalya, Isparta, Burdur, Adana, Mersin, } \\
\text { Hatay, Kahramanmaraş, Osmaniye }\end{array}$ \\
\hline $\begin{array}{l}\text { TR8/ } \\
\text { TR9 }\end{array}$ & $\begin{array}{l}\text { West Blacksea/ } \\
\text { East Blacksea }\end{array}$ & $\begin{array}{l}\text { Zonguldak, Karabük, Bartın, Kastamonu, } \\
\text { Cankır1, Sinop, Samsun, Tokat, Çorum, } \\
\text { Amasya, Trabzon, Ordu, Giresun, Rize, } \\
\text { Artvin, Gümüşhane }\end{array}$ \\
\hline $\begin{array}{l}\text { TRA/ } \\
\text { TRB }\end{array}$ & $\begin{array}{l}\text { NortheasternAnat } \\
\text { olia/ East Anatolia }\end{array}$ & $\begin{array}{l}\text { Erzurum, Erzincan, Bayburt, Ağrı, Kars, } \\
\text { Iğdır, Ardahan, Malatya, Elazı̆g, Bingöl, } \\
\text { Tunceli, Van, Muş, Bitlis, Hakkâri }\end{array}$ \\
\hline TRC & $\begin{array}{l}\text { Southeastern } \\
\text { Anatolia }\end{array}$ & $\begin{array}{l}\text { Gaziantep, Adıyaman, Kilis, Şanlıurfa, } \\
\text { Diyarbakır, Mardin, Batman, Şırnak, Siirt }\end{array}$ \\
\hline
\end{tabular}




\section{RESUlTS}

\section{A. Descriptive Statistics and Chi-Square Tests}

Socio-demographic and economic factors affecting ecommerce use of individuals are presented in Table II. The highest participation was in the 25-54 age group. The ratios of males and females were $48 \%$ and $52 \%$, respectively. It was observed that $24.6 \%$ of the individuals lived in the household with 4 individuals, while $14.2 \%$ of them lived in the household with 5 individuals. While $34.3 \%$ of the individuals were primary school graduates, $14.7 \%$ of them were university graduates. More than half $(57.5 \%)$ of the individuals who participated in the survey consisted of those who did not work in any job. Approximately $23 \%$ of the individuals were at the 1 st income level, $18 \%$ of them were at the 5 th income level. Furthermore, it was observed in Table II that the rate of ecommerce use increased by years and that the highest rate of ecommerce use was $58 \%$ in 2018.

TABLE II. FREQUENCY AND PERCENTAGES OF INDIVIDUALS ACCORDING TO THEIR E-COMMERCE USE

\begin{tabular}{|c|c|c|c|c|c|c|}
\hline \multirow{2}{*}{\multicolumn{2}{|c|}{ Variables }} & \multicolumn{3}{|l|}{ e-Commerce use } & \multirow{3}{*}{$\begin{array}{l}\text { n (\%) } \\
23752(18.3) \\
\end{array}$} & \multirow{3}{*}{$\begin{array}{l}\mathbf{P} \\
0.000^{2} \\
\end{array}$} \\
\hline & & \multirow{2}{*}{$\begin{array}{l}\begin{array}{l}\text { In the past three } \\
\text { months }\end{array} \\
1941(12.1) \\
\end{array}$} & \multirow{2}{*}{$\begin{array}{l}\begin{array}{l}\text { Before three } \\
\text { months }\end{array} \\
1514(14.4) \\
\end{array}$} & \multirow{2}{*}{$\begin{array}{l}\text { Never used } \\
20297(19.7)\end{array}$} & & \\
\hline \multirow{5}{*}{ Year } & 2014 & & & & & \\
\hline & 2015 & $2258(14.0)$ & $1640(15.6)$ & $18972(18.4)$ & $22870(17.6)$ & \\
\hline & 2016 & $2949(18.3)$ & $1917(18.2)$ & $20192(19.6)$ & $25058(19.3)$ & \\
\hline & 2017 & $3990(24.8)$ & $2682(25.5)$ & $22687(22.0)$ & $29359(22.6)$ & \\
\hline & 2018 & $4963(30.8)$ & $2782(26.4)$ & $20859(20.3)$ & $28604(22.1)$ & \\
\hline \multirow{6}{*}{ Age } & $15-24$ & $3821(23.7)$ & $2524(24.0)$ & $15325(14.9)$ & $21670(16.7)$ & $0.000^{\mathrm{a}}$ \\
\hline & $25-34$ & 6068 (37.7) & $3403(32.3)$ & $16232(15.8)$ & $25703(19.8)$ & \\
\hline & $35-44$ & $4072(25.3)$ & $2714(25.8)$ & $21221(20.6)$ & 28007 (21.6) & \\
\hline & $45-54$ & $1570(9.8)$ & $1293(12.3)$ & $21125(20.5)$ & $29388(18.5)$ & \\
\hline & $55-64$ & $474(2.9)$ & $510(4.8)$ & $17907(17.4)$ & $18891(14.6)$ & \\
\hline & $65+$ & $96(0.6)$ & $91(0.9)$ & $11197(10.9)$ & $11385(8.8)$ & \\
\hline \multirow{2}{*}{ Gender } & Male & 8794 (54.6) & $6171(58.6)$ & $46591(45.2)$ & $61556(47.5)$ & $0.000^{2}$ \\
\hline & Female & 7307 (45.4) & $4364(41.4)$ & $56416(54.8)$ & $68087(52.5$ & \\
\hline \multirow{5}{*}{$\begin{array}{l}\text { Educational } \\
\text { level }\end{array}$} & Did not finish a school & $46(0.3)$ & $76(0.7)$ & $18693(18.1)$ & $18815(14.5)$ & $0.000^{2}$ \\
\hline & Primary school & $873(5.4)$ & 1225 (11.6) & $42430(41.2)$ & $44528(34.3)$ & \\
\hline & Secondary school & $2321(14.4)$ & $2017(19.1)$ & $19277(18.7)$ & $23615(18.2)$ & \\
\hline & High school & $4890(30.4)$ & $3508(33.3)$ & $15241(14.8)$ & $23639(18.2)$ & \\
\hline & University & $7971(49.5)$ & 3709 (35.2) & $7366(7.2)$ & $19046(14.7)$ & \\
\hline \multirow{10}{*}{ Occupation } & Executives & $805(5)$ & $326(3.1)$ & $812(0.8)$ & $1943(1.5)$ & $0.000^{2}$ \\
\hline & Professional occupation & $3175(19.7)$ & $1328(12.6)$ & $2138(2.1)$ & $6641(5.1)$ & \\
\hline & $\begin{array}{l}\text { Mechanists, technicians and assistant } \\
\text { professional occupation }\end{array}$ & $505(3.1)$ & $219(2.1)$ & $409(0.4)$ & $1133(0.9)$ & \\
\hline & Staff working in office services & $1977(12.3)$ & $1000(9.5)$ & $2418(2.3)$ & $5395(4.2)$ & \\
\hline & Service and sales staff & $1913(11.9)$ & $1344(12.8)$ & $6718(6.5)$ & $9975(7.7)$ & \\
\hline & $\begin{array}{l}\text { Skilled agricultural, forestry and aquaculture } \\
\text { workers }\end{array}$ & $113(0.7)$ & $131(1.2)$ & $5314(5.2)$ & $5558(4.3)$ & \\
\hline & Artisans and employees in related jobs & $467(2.9)$ & $368(3.5)$ & $2309(2.2)$ & $3144(2.4)$ & \\
\hline & Plant and machine operators and installers & $342(2.1)$ & $292(2.8)$ & $1739(1.7)$ & $2373(1.8)$ & \\
\hline & Workers in elementary occupations & $1348(8.4)$ & $1325(12.6)$ & $16289(15.8)$ & $18962(14.6)$ & \\
\hline & Unemployed & $5456(33.9)$ & $4202(39.9)$ & $64861(63)$ & $74519(57.5)$ & \\
\hline \multirow{5}{*}{ Income } & $1^{\text {st }}$ income level (lowest) & $843(5.2)$ & $956(9.1)$ & $27954(27.1)$ & $29753(22.9)$ & $0.000^{\mathrm{a}}$ \\
\hline & $2^{\text {nd }}$ income level & $1581(9.8)$ & $1498(14.2)$ & $22639(22)$ & $25718(19.8)$ & \\
\hline & $3^{\text {rd }}$ income level & $2811(17.5)$ & $2309(21.9)$ & $22890(22.2)$ & $28010(21.6)$ & \\
\hline & $4^{\text {th }}$ income level & $3498(21.7)$ & $2418(23)$ & $16839(16.3)$ & 22755 (17.6) & \\
\hline & $5^{\text {th }}$ income level (highest) & $7368(45.8)$ & $3354(31.8)$ & $12685(12.3)$ & $23407(18.1)$ & \\
\hline \multirow{7}{*}{ Region } & TR1 & $3263(20.3)$ & $1790(17)$ & $12662(12.3)$ & $17715(13.7)$ & $0.000^{2}$ \\
\hline & TR2/TR4 & $2713(16.8)$ & 1644 (15.6) & $15285(14.8)$ & $19642(15.2)$ & \\
\hline & TR3 & 1908 (11.9) & $1410(13.4)$ & $11043(10.7)$ & $14361(11.1)$ & \\
\hline & TR6 & $1543(9.6)$ & $1338(12.7)$ & $10688(10.4)$ & $13569(10.5)$ & \\
\hline & TR5/TR7 & $2969(18.4)$ & $1721(16.3)$ & $16282(15.8)$ & $20972(16.2)$ & \\
\hline & TR8/TR9 & $1741(10.8)$ & $1259(12)$ & $13257(12.9)$ & $16257(12.5)$ & \\
\hline & TRC & $795(4.9)$ & $535(5.1)$ & $10393(10.1)$ & $11723(9)$ & \\
\hline
\end{tabular}




\begin{tabular}{|c|c|c|c|c|c|c|}
\hline & TRA/TRB & 1169 (7.3) & $838(8)$ & 13397 (13) & 15404 (11.9) & \\
\hline \multirow{5}{*}{ Household size } & 2 and fewer & $3372(20.9)$ & $1947(18.5)$ & $23577(22.9)$ & $28896(22.3)$ & $0.000^{\mathrm{a}}$ \\
\hline & 3 people & $4946(30.7)$ & $2916(27.7)$ & $20564(20)$ & $28426(21.9)$ & \\
\hline & 4 people & $4866(30.2)$ & $3271(31)$ & $23715(23)$ & $31852(24.6)$ & \\
\hline & 5 people & $1881(11.7)$ & 1448 (13.7) & $15095(14.7)$ & $18424(14.2)$ & \\
\hline & 6 and more & $1036(6.4)$ & $953(9)$ & $20056(19.5)$ & $22045(17)$ & \\
\hline
\end{tabular}

According to the results of chi-square test of independence, a significant relationship was found between the status of ecommerce use of individuals and socio-economic and demographic variables in the study.

\section{B. Estimation of Models}

The multinomial logistic regression and multinomial probit regression analyses were employed to detect the factors affecting e-commerce use of individuals over the age of 15 years included in the study. Ordinal and nominal variables were defined as dummy variables to observed the effects of the categories of all variables to be included in multinomial logistic and multinomial probit regression models [35].

Whether there was multicollinearity between independent variables to be included in the multinomial logistic and multinomial probit regression model was tested. It was considered that those with a variance inflation factor (VIF) value of 5 and above led to moderate multicollinearity, and those with a VIF value of 10 and above led to higher multicollinearity [33]. As seen in Table III, none of the independent variable included in the model had 5 or more variance inflation factors. Accordingly, there was no variable that led to multicollinearity problem among the variables in the model.

The results of the estimated multinomial logistic regression and multinomial probit regression model are presented in Table III. In the models, the "never used" category of the dependent variable was considered as the reference category. According to test results, multinomial logistic regression model provides the assumption of independence of irrelevant alternatives.

When Table III was examined, it was observed that the variables of year $(2015,2016,2017,2018)$, age (15-24, 25-24, 35-44, 45-54, 55-64, 65+), educational level (primary school, secondary school, high school, university), occupation (executives; professional occupation members; mechanists, technicians and assistant professional occupation members; staff working in office services; service and sales staff; skilled agricultural, forestry and aquaculture workers; artisans and employees in related jobs; workers in elementary occupations), income level, region (TR1, TR2/TR4, TR3, TR/6, TR5/TR7 and TR8/TR9) and household size ( 2 and fewer, 3 people, 4 people, 5 people, 6 and more) were statistically significant.

\section{Average Direct Elasticity}

The average direct elasticities values of socio-demographic and economic factors affecting e-commerce use of individuals in Turkey are presented in Table IV.
The comparison criteria of the models used in the study are presented in Table V. According to Table V, it can be said that the multinomial probit regression model with the lowest AIC (Akaike Information Criterion) and BIC (Bayesian Information Criterion) values was the best model.

According to the multinomial probit regression model presented in Table IV, while other variables were fixed, an individual who participated in the study in 2018 was $135.6 \%$ more likely to use e-commerce in the past three months and $74.7 \%$ more likely to use e-commerce before three months compared to 2014. An individual who participated in the study in 2015, 2016 and 2017 was $31.5 \%, 57.6 \%$ and $92.7 \%$ more likely to use e-commerce in the past three months, respectively, compared to the reference category.

Individuals aged between 15 and 24 years were $389.3 \%$ more likely to use e-commerce in the past three months and $271.3 \%$ more likely to use e-commerce before three months compared to the $65+$ age (reference category) group. The fact that the individual was in the 25-34, 35-44, 45-54 and 55-64 age group increased the possibility of using e-commerce in the past three months by $369 \%, 328.8 \%, 225.3 \%$ and $103.8 \%$, respectively, compared to the reference group. Females were $19.7 \%$ less likely to use e-commerce in the past three months and $36.4 \%$ less likely to use e-commerce before three months compared to males.

University graduate individuals were $350.5 \%$ more likely to use e-commerce in the past three months and $260.5 \%$ more likely to use e-commerce before three months compared to those who did not finish a school (reference category). Having graduated from primary school, secondary school and high school increased the possibility of using e-commerce in the past three months by $130.9 \%, 208.1 \%$ and $292.8 \%$, respectively, compared to the reference group.

Executive individuals were $112.1 \%$ more likely to use ecommerce in the past three months and $50.6 \%$ more likely to use e-commerce before three months compared to unemployed individuals (reference category). Professional occupation members, mechanists/technicians/assistant professional occupation members, staff working in office services, service/sales staff, artisans/employees in related jobs and plant and machine operators/installers increased the possibility of using e-commerce in the past three months by $80.4 \%, 94.1 \%$, $78.7 \%, 36.9 \%, 38.3 \%$ and $4.2 \%$, respectively, compared to the reference category. Skilled agricultural/forestry/aquaculture workers and the workers in elementary occupations decreased the possibility of using e-commerce in the past three months by $73.2 \%$ and $19.7 \%$, respectively, compared to the reference category. 
TABLE III. MULTINOMIAL LOGISTIC REGRESSION AND MULTINOMIAL PROBIT REGRESSION MODEL RESULTS

\begin{tabular}{|c|c|c|c|c|c|c|c|c|c|}
\hline \multirow{3}{*}{ Variables } & \multicolumn{4}{|c|}{ Multinomial Logistic Regression } & \multicolumn{4}{|c|}{ Multinomial Probit Regression } & \multirow{3}{*}{ VIF } \\
\hline & \multicolumn{2}{|c|}{$\begin{array}{l}\text { In the past three } \\
\text { months }\end{array}$} & \multicolumn{2}{|c|}{$\begin{array}{l}\text { Before three } \\
\text { months }\end{array}$} & \multicolumn{2}{|c|}{$\begin{array}{l}\text { In the past three } \\
\text { months }\end{array}$} & \multicolumn{2}{|c|}{$\begin{array}{l}\text { Before three } \\
\text { months }\end{array}$} & \\
\hline & $\boldsymbol{\beta}$ & Std. Error & $\boldsymbol{\beta}$ & $\begin{array}{l}\text { Std. } \\
\text { Error }\end{array}$ & $\boldsymbol{\beta}$ & Std. Error & $\boldsymbol{\beta}$ & $\begin{array}{l}\text { Std. } \\
\text { Error }\end{array}$ & \\
\hline \multicolumn{10}{|l|}{ Year (reference category: 2014) } \\
\hline 2015 & $0.265^{\mathrm{a}}$ & 0.041 & $0.182^{\mathrm{a}}$ & 0.043 & $0.202^{\mathrm{a}}$ & 0.030 & $0.135^{\mathrm{a}}$ & 0.030 & 1.63 \\
\hline 2016 & $0.485^{\mathrm{a}}$ & 0.039 & $0.314^{\mathrm{a}}$ & 0.042 & $0.374^{\mathrm{a}}$ & 0.029 & $0.234^{\mathrm{a}}$ & 0.029 & 1.67 \\
\hline 2017 & $0.831^{\mathrm{a}}$ & 0.037 & $0.607^{\mathrm{a}}$ & 0.039 & $0.631^{\mathrm{a}}$ & 0.028 & $0.447^{\mathrm{a}}$ & 0.027 & 1.75 \\
\hline 2018 & $1.272^{\mathrm{a}}$ & 0.037 & $0.871^{\mathrm{a}}$ & 0.040 & $0.961^{\mathrm{a}}$ & 0.027 & $0.643^{\mathrm{a}}$ & 0.028 & 1.74 \\
\hline \multicolumn{10}{|l|}{ Age (reference category: $65+$ ) } \\
\hline \begin{tabular}{l|l} 
& $15-24$ \\
\end{tabular} & $3.376^{\mathrm{a}}$ & 0.117 & $2.733^{\mathrm{a}}$ & 0.123 & $2.447^{\mathrm{a}}$ & 0.077 & $1.899^{\mathrm{a}}$ & 0.076 & 3.47 \\
\hline $25-34$ & $3.149^{\mathrm{a}}$ & 0.116 & $2.641^{\mathrm{a}}$ & 0.122 & $2.278^{\mathrm{a}}$ & 0.076 & $1.829^{\mathrm{a}}$ & 0.075 & 3.51 \\
\hline $35-44$ & $2.726^{\mathrm{a}}$ & 0.117 & $2.372^{\mathrm{a}}$ & 0.123 & $1.953^{\mathrm{a}}$ & 0.077 & $1.619^{\mathrm{a}}$ & 0.075 & 3.64 \\
\hline $45-54$ & $1.734^{\mathrm{a}}$ & 0.118 & $1.605^{\mathrm{a}}$ & 0.123 & $1.226^{\mathrm{a}}$ & 0.078 & $1.054^{\mathrm{a}}$ & 0.075 & 2.98 \\
\hline $55-64$ & $0.794^{\mathrm{a}}$ & 0.123 & $0.898^{\mathrm{a}}$ & 0.127 & $0.529^{\mathrm{a}}$ & 0.081 & $0.559^{\mathrm{a}}$ & 0.078 & 2.35 \\
\hline \multicolumn{10}{|l|}{ Gender (reference category: male) } \\
\hline \begin{tabular}{l|l} 
& Female \\
\end{tabular} & $-0.208^{\mathrm{a}}$ & 0.026 & $-0.358^{\mathrm{a}}$ & 0.028 & $-0.161^{\mathrm{a}}$ & 0.019 & $-0.263^{\mathrm{a}}$ & 0.020 & 1.35 \\
\hline \multicolumn{10}{|c|}{ Educational level (reference category: did not finish a school) } \\
\hline \begin{tabular}{l|l} 
& Primary school \\
\end{tabular} & $1.324^{\mathrm{a}}$ & 0.172 & $1.245^{\mathrm{a}}$ & 0.137 & $0.753^{\mathrm{a}}$ & 0.091 & $0.693^{\mathrm{a}}$ & 0.072 & 2.60 \\
\hline Secondary school & $2.153^{\mathrm{a}}$ & 0.171 & $1.848^{\mathrm{a}}$ & 0.139 & $1.274^{\mathrm{a}}$ & 0.090 & $1.102^{\mathrm{a}}$ & 0.073 & 2.59 \\
\hline High school & $3.065^{\mathrm{a}}$ & 0.170 & $2.591^{\mathrm{a}}$ & 0.138 & $1.972^{\mathrm{a}}$ & 0.089 & $1.678^{\mathrm{a}}$ & 0.072 & 2.60 \\
\hline University & $3.788^{\mathrm{a}}$ & 0.170 & $3.110^{\mathrm{a}}$ & 0.139 & $2.082^{\mathrm{a}}$ & 0.074 & $2.082^{\mathrm{a}}$ & 0.074 & 3.04 \\
\hline \multicolumn{10}{|l|}{ Occupation (reference category: unemployed) } \\
\hline \begin{tabular}{l|l} 
Executives \\
\end{tabular} & $1.106^{\mathrm{a}}$ & 0.070 & $0.660^{\mathrm{a}}$ & 0.084 & $0.510^{\mathrm{a}}$ & 0.061 & $0.510^{\mathrm{a}}$ & 0.061 & 1.12 \\
\hline Professional occupation & $0.741^{\mathrm{a}}$ & 0.046 & $0.493^{\mathrm{a}}$ & 0.055 & $0.390^{\mathrm{a}}$ & 0.040 & $0.390^{\mathrm{a}}$ & 0.040 & 1.55 \\
\hline $\begin{array}{l}\text { Mechanists, technicians and assistant } \\
\text { professional }\end{array}$ & $0.894^{\mathrm{a}}$ & 0.089 & $0.614^{\mathrm{a}}$ & 0.105 & $0.478^{\mathrm{a}}$ & 0.076 & $0.478^{\mathrm{a}}$ & 0.076 & 1.07 \\
\hline Staff working in office services & $0.740^{\mathrm{a}}$ & 0.046 & $0.534^{\mathrm{a}}$ & 0.052 & $0.426^{\mathrm{a}}$ & 0.038 & $0.426^{\mathrm{a}}$ & 0.038 & 1.21 \\
\hline Service and sales staff & $0.334^{\mathrm{a}}$ & 0.040 & $0.286^{\mathrm{a}}$ & 0.044 & $0.227^{\mathrm{a}}$ & 0.031 & $0.227^{\mathrm{a}}$ & 0.031 & 1.22 \\
\hline $\begin{array}{l}\text { Skilled agricultural, forestry and aquaculture } \\
\text { workers }\end{array}$ & $-0.688^{\mathrm{a}}$ & 0.113 & $-0.511^{\mathrm{a}}$ & 0.107 & $-0.343^{\mathrm{a}}$ & 0.068 & $-0.343^{\mathrm{a}}$ & 0.068 & 1.10 \\
\hline Artisans and employees in related jobs & $0.341^{\mathrm{a}}$ & 0.070 & $0.257^{\mathrm{a}}$ & 0.072 & $0.208^{\mathrm{a}}$ & 0.051 & $0.208^{\mathrm{a}}$ & 0.051 & 1.09 \\
\hline Plant and machine operators and installers & 0.035 & 0.078 & 0.109 & 0.081 & 0.090 & 0.058 & 0.090 & 0.058 & 1.08 \\
\hline Workers in elementary & $-0.212^{\mathrm{a}}$ & 0.042 & $-0.095^{\mathrm{b}}$ & 0.042 & $-0.068^{\mathrm{a}}$ & 0.029 & $-0.068^{\mathrm{b}}$ & 0.029 & 1.30 \\
\hline \multicolumn{10}{|c|}{ Income level (reference category: $1^{\text {st }}$ income level (lowest)) } \\
\hline \begin{tabular}{l|l} 
nd & income level \\
\end{tabular} & $0.367^{\mathrm{a}}$ & 0.053 & $0.282^{\mathrm{a}}$ & 0.050 & $0.203^{\mathrm{a}}$ & 0.033 & $0.203^{\mathrm{a}}$ & 0.033 & 1.59 \\
\hline $3^{\text {rd }}$ income level & $0.746^{\mathrm{a}}$ & 0.049 & $0.574^{\mathrm{a}}$ & 0.047 & $0.419^{\mathrm{a}}$ & 0.032 & $0.419^{\mathrm{a}}$ & 0.032 & 1.70 \\
\hline $4^{\text {th }}$ income level & $1.002^{\mathrm{a}}$ & 0.049 & $0.68^{\mathrm{a}}$ & 0.048 & $0.504^{\mathrm{a}}$ & 0.033 & $0.504^{\mathrm{a}}$ & 0.033 & 1.72 \\
\hline \begin{tabular}{l|l}
$5^{\text {th }}$ income level (highest) \\
\end{tabular} & $1.543^{\mathrm{a}}$ & 0.049 & $0.937^{\mathrm{a}}$ & 0.050 & $0.700^{\mathrm{a}}$ & 0.034 & $0.700^{\mathrm{a}}$ & 0.034 & 2.10 \\
\hline \multicolumn{10}{|l|}{ Region (reference category: TRA/TRB) } \\
\hline \begin{tabular}{l|l|} 
TR1 \\
\end{tabular} & $0.369^{\mathrm{a}}$ & 0.050 & $0.240^{\mathrm{a}}$ & 0.055 & $0.180^{\mathrm{a}}$ & 0.038 & $0.180^{\mathrm{a}}$ & 0.0381 & 2.08 \\
\hline TR2/TR4 & $0.336^{\mathrm{a}}$ & 0.052 & $0.185^{\mathrm{a}}$ & 0.056 & $0.139^{\mathrm{a}}$ & 0.038 & $0.139^{\mathrm{a}}$ & 0.0384 & 2.16 \\
\hline TR3 & $0.291^{\mathrm{a}}$ & 0.054 & $0.370^{\mathrm{a}}$ & 0.057 & $0.267^{\mathrm{a}}$ & 0.039 & $0.267^{\mathrm{a}}$ & 0.0394 & 1.88 \\
\hline TR6 & $0.253^{\mathrm{a}}$ & 0.055 & $0.435^{\mathrm{a}}$ & 0.057 & $0.308^{\mathrm{a}}$ & 0.040 & $0.308^{\mathrm{a}}$ & 0.0398 & 1.79 \\
\hline TR5/TR7 & $0.228^{\mathrm{a}}$ & 0.050 & 0.069 & 0.055 & $0.058^{\mathrm{a}}$ & 0.038 & 0.058 & 0.0377 & 2.15 \\
\hline TR8/TR9 & $0.297^{\mathrm{a}}$ & 0.054 & $0.323^{\mathrm{a}}$ & 0.058 & $0.233^{\mathrm{a}}$ & 0.040 & $0.233^{\mathrm{a}}$ & 0.0399 & 1.91 \\
\hline TRC & -0.062 & 0.064 & $-0.157^{\mathrm{b}}$ & 0.069 & -0.099 & 0.047 & $-0.099^{\mathrm{b}}$ & 0.0469 & 1.62 \\
\hline \multicolumn{10}{|l|}{ Household size (reference category: 2 and fewer) } \\
\hline 3 people & $-0.277^{\mathrm{a}}$ & 0.035 & $-0.227^{\mathrm{a}}$ & 0.038 & $-0.160^{\mathrm{a}}$ & 0.027 & $-0.160^{\mathrm{a}}$ & 0.0272 & 1.73 \\
\hline 4 people & $-0.533^{\mathrm{a}}$ & 0.035 & $-0.381^{\mathrm{a}}$ & 0.039 & $-0.278^{\mathrm{a}}$ & 0.027 & $-0.278^{\mathrm{a}}$ & 0.0274 & 1.96 \\
\hline 5 people & $-0.733^{\mathrm{a}}$ & 0.044 & $-0.525^{\mathrm{a}}$ & 0.047 & $-0.385^{\mathrm{a}}$ & 0.033 & $-0.385^{\mathrm{a}}$ & 0.0328 & 1.70 \\
\hline 6 and more & $-1.196^{\mathrm{a}}$ & 0.051 & $-0.830^{\mathrm{a}}$ & 0.053 & $-0.614^{\mathrm{a}}$ & 0.036 & $-0.614^{\mathrm{a}}$ & 0.0364 & 1.98 \\
\hline
\end{tabular}


TABLE IV. MULTINOMIAL LOGISTIC REGRESSION AND MULTINOMIAL PROBIT REGRESSION MODEL RESULTS AND MARGINAL EFFECTS

\begin{tabular}{|c|c|c|c|c|c|c|}
\hline \multirow{3}{*}{ Variables } & \multicolumn{3}{|c|}{ Multinomial Logistic Regression } & \multicolumn{3}{|c|}{ Multinomial Probit Regression } \\
\hline & $\begin{array}{l}\text { In the past } \\
\text { three } \\
\text { months }\end{array}$ & $\begin{array}{l}\text { Before three } \\
\text { months }\end{array}$ & Never used & $\begin{array}{l}\text { In the past } \\
\text { three } \\
\text { months }\end{array}$ & $\begin{array}{l}\text { Before three } \\
\text { months }\end{array}$ & Never used \\
\hline & ey/dx $(\%)$ & ey/dx $(\%)$ & ey/dx $(\%)$ & ey/dx $(\%)$ & $\mathrm{ey} / \mathrm{dx}(\%)$ & ey/dx $(\%)$ \\
\hline \multicolumn{7}{|l|}{ Year (reference category: 2014) } \\
\hline 2015 & $22.4^{\mathrm{a}}$ & $14.1^{\mathrm{a}}$ & $-4.1^{\mathrm{a}}$ & $31.5^{\mathrm{a}}$ & $17.6^{\mathrm{a}}$ & $-4.0^{\mathrm{a}}$ \\
\hline 2016 & $40.7^{\mathrm{a}}$ & $23.6^{\mathrm{a}}$ & $-7.8^{\mathrm{a}}$ & $57.6^{\mathrm{a}}$ & $29.3^{\mathrm{a}}$ & $-7.7^{\mathrm{a}}$ \\
\hline 2017 & $67.9^{\mathrm{a}}$ & $45.6^{\mathrm{a}}$ & $-15.2^{\mathrm{a}}$ & $92.7^{\mathrm{a}}$ & $55.3^{\mathrm{a}}$ & $-14.9^{\mathrm{a}}$ \\
\hline 2018 & $102.0^{\mathrm{a}}$ & $61.9^{\mathrm{a}}$ & $-25.2^{\mathrm{a}}$ & $135.6^{\mathrm{a}}$ & $74.7^{\mathrm{a}}$ & $-24.7^{\mathrm{a}}$ \\
\hline \multicolumn{7}{|l|}{ Age (reference category: 65 +) } \\
\hline $15-24$ & $293.6^{\mathrm{a}}$ & $229.3^{\mathrm{a}}$ & $-44.0^{\mathrm{a}}$ & $389.3^{\mathrm{a}}$ & $271.3^{\mathrm{a}}$ & $-43.2^{\mathrm{a}}$ \\
\hline $25-34$ & $275.9^{\mathrm{a}}$ & $225.1^{\mathrm{a}}$ & $-39.0^{\mathrm{a}}$ & $369.0^{\mathrm{a}}$ & $267.0^{\mathrm{a}}$ & $-38.3^{\mathrm{a}}$ \\
\hline $35-44$ & $242.8^{\mathrm{a}}$ & $207.3^{\mathrm{a}}$ & $-29.8^{\mathrm{a}}$ & $328.8^{\mathrm{a}}$ & $246.3^{\mathrm{a}}$ & $-29.0^{\mathrm{a}}$ \\
\hline $45-54$ & $159.8^{\mathrm{a}}$ & $146.9^{\mathrm{a}}$ & $-13.6^{\mathrm{a}}$ & $225.3^{\mathrm{a}}$ & $175.7^{\mathrm{a}}$ & $-13.2^{\mathrm{a}}$ \\
\hline $55-64$ & $74.6^{\mathrm{a}}$ & $85.0^{\mathrm{a}}$ & $-4.8^{\mathrm{a}}$ & $103.8^{\mathrm{a}}$ & $101.3^{\mathrm{a}}$ & $-4.6^{\mathrm{a}}$ \\
\hline \multicolumn{7}{|l|}{ Gender (reference category: male) } \\
\hline Female & $-14.9^{\mathrm{a}}$ & $-29.9^{\mathrm{a}}$ & $5.8^{\mathrm{a}}$ & $-19.7^{\mathrm{a}}$ & $-36.4^{\mathrm{a}}$ & $5.9^{\mathrm{a}}$ \\
\hline \multicolumn{7}{|c|}{ Educational level (reference category: did not finish a school) } \\
\hline \begin{tabular}{l|l} 
Primary school \\
\end{tabular} & $124.8^{\mathrm{a}}$ & $116.8^{\mathrm{a}}$ & $-7.6^{\mathrm{a}}$ & $130.9^{\mathrm{a}}$ & $112.3^{\mathrm{a}}$ & $-7.2^{\mathrm{a}}$ \\
\hline Secondary school & $198.3^{\mathrm{a}}$ & $167.7^{\mathrm{a}}$ & $-17.0^{\mathrm{a}}$ & $208.1^{\mathrm{a}}$ & $166.4^{\mathrm{a}}$ & $-15.6^{\mathrm{a}}$ \\
\hline High school & $270.8^{\mathrm{a}}$ & $223.5^{\mathrm{a}}$ & $-36.7^{\mathrm{a}}$ & $292.8^{\mathrm{a}}$ & $229.2^{\mathrm{a}}$ & $-34.2^{\mathrm{a}}$ \\
\hline University & $321.5^{\mathrm{a}}$ & $253.8^{\mathrm{a}}$ & $-57.3^{\mathrm{a}}$ & $350.5^{\mathrm{a}}$ & $260.5^{\mathrm{a}}$ & $-56.3^{\mathrm{a}}$ \\
\hline \multicolumn{7}{|l|}{ Occupation (reference category: unemployed) } \\
\hline \begin{tabular}{l|l} 
Executives \\
\end{tabular} & $86.3^{\mathrm{a}}$ & $41.7^{\mathrm{a}}$ & $-24.3^{\mathrm{a}}$ & $112.1^{\mathrm{a}}$ & $50.6^{\mathrm{a}}$ & $-24.6^{\mathrm{a}}$ \\
\hline Professional occupation & $58.6^{\mathrm{a}}$ & $33.8^{\mathrm{a}}$ & $-15.5^{\mathrm{a}}$ & $80.4^{\mathrm{a}}$ & $42.0^{\mathrm{a}}$ & $-16.2^{\mathrm{a}}$ \\
\hline Mechanists, technicians and assistant professional & $69.8^{\mathrm{a}}$ & $41.8^{\mathrm{a}}$ & $-19.6^{\mathrm{a}}$ & $94.1^{\mathrm{a}}$ & $50.9^{\mathrm{a}}$ & $-20.3^{\mathrm{a}}$ \\
\hline Staff working in office services & $58.1^{\mathrm{a}}$ & $33.8^{\mathrm{a}}$ & $-15.5^{\mathrm{a}}$ & $78.7^{\mathrm{a}}$ & $47.4^{\mathrm{a}}$ & $-16.6^{\mathrm{a}}$ \\
\hline Service and sales staff & $26.5^{\mathrm{a}}$ & $21.6^{\mathrm{a}}$ & $6.9^{\mathrm{a}}$ & $36.9^{\mathrm{a}}$ & $27.7^{\mathrm{a}}$ & $-7.3^{\mathrm{a}}$ \\
\hline Skilled agricultural, forestry and aquaculture workers & $-58.4^{\mathrm{a}}$ & $-40.6^{\mathrm{a}}$ & $10.4^{\mathrm{a}}$ & $-73.2^{\mathrm{a}}$ & $-45.2^{\mathrm{a}}$ & $9.4^{\mathrm{a}}$ \\
\hline Artisans and employees in related jobs & $27.3^{\mathrm{a}}$ & $19.0^{\mathrm{a}}$ & $-6.8^{\mathrm{a}}$ & $38.3^{\mathrm{a}}$ & $24.6^{\mathrm{a}}$ & $-7.1^{\mathrm{a}}$ \\
\hline Plant and machine operators and installers & 2.2 & 9.6 & -1.4 & 4.2 & 12.9 & -1.7 \\
\hline Workers in elementary & $-18.0^{\mathrm{a}}$ & $-6.4^{\mathrm{c}}$ & $3.1^{\mathrm{a}}$ & $-19.7^{\mathrm{a}}$ & $-7.8^{\mathrm{c}}$ & $2.6^{\mathrm{a}}$ \\
\hline \multicolumn{7}{|l|}{ Income level (reference category: $\mathbf{1}^{\text {st }}$ income level (lowest)) } \\
\hline $2^{\text {nd }}$ income level & $31.5^{\mathrm{a}}$ & $23.1^{\mathrm{a}}$ & $-5.2^{\mathrm{a}}$ & $41.7^{\mathrm{a}}$ & $27.7^{\mathrm{a}}$ & $-4.9^{\mathrm{a}}$ \\
\hline $3^{\text {rd }}$ income level & $62.9^{\mathrm{a}}$ & $45.7^{\mathrm{a}}$ & $-11.7^{\mathrm{a}}$ & $82.7^{\mathrm{a}}$ & $54.9^{\mathrm{a}}$ & $-11.3^{\mathrm{a}}$ \\
\hline $4^{\text {th }}$ income level & $84.3^{\mathrm{a}}$ & $52.1^{\mathrm{a}}$ & $-15.9^{\mathrm{a}}$ & $109.3^{\mathrm{a}}$ & $63.1^{\mathrm{a}}$ & $-15.4^{\mathrm{a}}$ \\
\hline $5^{\text {th }}$ income level (highest) & $127.1^{\mathrm{a}}$ & $66.5^{\mathrm{a}}$ & $-27.2^{\mathrm{a}}$ & $163.1^{\mathrm{a}}$ & $80.0^{\mathrm{a}}$ & $-26.5^{\mathrm{a}}$ \\
\hline \multicolumn{7}{|l|}{ Region (reference category: TRA/TRB) } \\
\hline \begin{tabular}{l|l|} 
TR1 \\
\end{tabular} & $30.1^{\mathrm{a}}$ & $17.2^{\mathrm{a}}$ & $-6.8^{\mathrm{a}}$ & $39.5^{\mathrm{a}}$ & $21.6^{\mathrm{a}}$ & $-6.6^{\mathrm{a}}$ \\
\hline TR2/TR4 & $27.7^{\mathrm{a}}$ & $12.6^{\mathrm{b}}$ & $-5.8^{\mathrm{a}}$ & $37.3^{\mathrm{a}}$ & $15.8^{\mathrm{a}}$ & $-5.7^{\mathrm{a}}$ \\
\hline TR3 & $22.2^{\mathrm{a}}$ & $30.1^{\mathrm{a}}$ & $-6.9^{\mathrm{a}}$ & $29.2^{\mathrm{a}}$ & $36.0^{\mathrm{a}}$ & $-6.7^{\mathrm{a}}$ \\
\hline TR6 & $18.2^{\mathrm{a}}$ & $36.4^{\mathrm{a}}$ & $-7.1^{\mathrm{a}}$ & $24.0^{\mathrm{a}}$ & $42.7^{\mathrm{a}}$ & $-6.9^{\mathrm{a}}$ \\
\hline TR5/TR7 & $19.4^{\mathrm{a}}$ & 3.5 & $-3.4^{\mathrm{a}}$ & $26.6^{\mathrm{a}}$ & 5.1 & $-3.4^{\mathrm{a}}$ \\
\hline TR8/TR9 & $23.2^{\mathrm{a}}$ & $25.8^{\mathrm{a}}$ & $-6.5^{\mathrm{a}}$ & $30.1^{\mathrm{a}}$ & $31.0^{\mathrm{a}}$ & $-6.3^{\mathrm{a}}$ \\
\hline \begin{tabular}{|l|l|} 
TRC \\
\end{tabular} & -4.3 & $-13.9^{\mathrm{b}}$ & $1.9^{\mathrm{a}}$ & -2.8 & $-15.2^{\mathrm{b}}$ & 1.5 \\
\hline \multicolumn{7}{|l|}{ Household size (reference: 2 and fewer) } \\
\hline \begin{tabular}{l|l}
3 people \\
\end{tabular} & $-20.9^{\mathrm{a}}$ & $-15.9^{\mathrm{a}}$ & $6.7^{\mathrm{a}}$ & $-27.2^{\mathrm{a}}$ & $-17.6^{\mathrm{a}}$ & $6.6^{\mathrm{a}}$ \\
\hline 4 people & $-41.5^{\mathrm{a}}$ & $-26.3^{\mathrm{a}}$ & $11.8^{\mathrm{a}}$ & $-54.3^{\mathrm{a}}$ & $-30.7^{a}$ & $11.6^{\mathrm{a}}$ \\
\hline 5 people & $-57.8^{\mathrm{a}}$ & $-36.9^{\mathrm{a}}$ & $15.5^{\mathrm{a}}$ & $-74.2^{\mathrm{a}}$ & $-43.9^{\mathrm{a}}$ & $15.0^{\mathrm{a}}$ \\
\hline 6 and more & $-96.9^{a}$ & $-60.3^{\mathrm{a}}$ & $22.7^{\mathrm{a}}$ & $-128.4^{\mathrm{a}}$ & $-73.2^{\mathrm{a}}$ & $22.1^{\mathrm{a}}$ \\
\hline
\end{tabular}


TABLE V. COMPARISON OF MULTINOMIAL MODELS

\begin{tabular}{|l|l|l|}
\hline Criteria & MLOGIT & MPROBIT \\
\hline AIC & 119786.06 & 119670.38 \\
\hline BIC & 120548.32 & 120432.64 \\
\hline Log-likelihood & -59815.03 & -59757.9 \\
\hline P-value & 0.000 & 0.000 \\
\hline N & 129,643 & 129,643 \\
\hline
\end{tabular}

Individuals with the highest income were $163.1 \%$ more likely to use e-commerce in the past three months and $80 \%$ more likely to use e-commerce before three months compared to the lowest income group. Being at the 2nd, 3rd and 4th income levels increased the possibility of using e-commerce in the past three months by $41.7 \%, 82.7 \%$ and $109.3 \%$, respectively, compared to the reference category. Individuals living in TR1 (Istanbul) region were 39.5\% more likely to use e-commerce in the past three months and $21.6 \%$ more likely to use e-commerce before three months compared to TRA/TRB (Northeastern Anatolia/Middle East Anatolia) region.

Individuals with 3 people in their households were $27.2 \%$ less likely to use e-commerce in the past three months and $17.6 \%$ less likely to use e-commerce before three months compared to those with 2 and fewer people in their households (reference category). Individuals with 4 people, 5 people and 6 and more people in their households decreased the possibility of using e-commerce in the past three months by $54.3 \%, 74.2 \%$ and $128.4 \%$, respectively, compared to the reference category.

\section{DISCUSSION}

The shopping methods and habits of users have changed with the effect of digitalization all over the world. Especially because of its advantages such as product range, affordable prices, comparability offered by online shopping, the number of users who prefer this method is increasing day by day. Nevertheless, disadvantages of online shopping, such as inability to directly examine the product to be purchased, the fact that return and exchange may take time, sharing personal information (ID number, card number, account, address information etc.), security vulnerabilities of websites, and cheating with fake sites, may also affect the shopping preferences of users.

The aim of this study was to detect the socio-economic and demographic factors affecting online shopping of individuals in Turkey. Multinomial logistic and multinomial probit regression analyses were employed to detect the factors affecting ecommerce use of individuals in Turkey.

According to the analysis results, it was determined that the year of survey was an effective variable on e-commerce use. With the increasing compliance with technology and the widespread use of technology, individuals' expected possibility of using e-commerce also continuously increases as the year increases. In the study, it was determined that the age of the individuals also significantly affected e-commerce use. Individuals at a young age were more likely to use e-commerce than the elderly. Individuals' expected possibility of using ecommerce decreases as the age increases. Similar results were obtained in the literature [36-38]. In a study in which the consumer behaviors of online shoppers in Bangladesh were examined, it was observed that most of the e-commerce users consisted of individuals under the age of 40 for reasons such as saving time, price flexibility and product range [39]. Another study confirming the results was conducted in Oman, and it was indicated that the young population had the most intensive e-commerce use and that their expectations were slightly different from other groups of people [40]. In a review conducted to find out how young consumers learned to do shopping, adolescence (9-14 years) was stated to be the most important time period in socialization [41]. Furthermore, it was stated that the increase in e-commerce preferences of users in this period resulted from the fact that children and young people, as online consumers, considered internet as an important means of socialization due to its two-way communication ability which helps them use their competence [42]. It is indicated that generations affect e-commerce attitudes according to the age range of individuals. In a study conducted in Malaysia, it was stated that e-commerce was mostly preferred by the individuals of the Y Generation (20-40 years old) and it was detected that the perceived trust in purchase intentions of this generation members was determinant [43]. In another study, the statistics of users who ordered or purchased a product over the internet between 2008 and 2018 were analyzed according to their age groups. In that study, it was indicated that the most e-commerce activities were between the ages of 25-54 according to average level of use, and the 16-24 age group increased above the average especially after 2014 [22].

In the study, it was detected that females were less likely to use e-commerce both in the past three months and before three months compared to males. Similar results were also obtained in the studies conducted in the literature [44-46]. In another study in which the effect of gender difference, age and occupational group on shopping methods was investigated, it was determined that e-commerce use was more preferred by men during the research period. It was stated that store shopping was mostly preferred by women. Furthermore, it was observed that male individuals generally changed their shopping methods due to service quality, product range and pricing [47].

One of the factors affecting e-commerce use is the educational levels of individuals. In the study, individuals' expected possibility of using e-commerce increased as the educational level increased. It was detected that similar results were found in some studies conducted in the literature [48-50]. In another study supporting the results, it was remarked that online consumers were more educated (university students) than the general population and therefore the educational level was effective on online shopping [51]. A similar study was conducted in Thailand, and according to the results obtained, it was determined that the segment who did the most shopping over the internet consisted of university students [52]. In another study in which the effects of educational level on online shopping habit were investigated, it was indicated that the fact that university students were further affected by family, friends and social media was decisive in their preference for this method more [53]. It was also observed that educational level was more effective on people purchasing tickets online compared to other factors [54]. 
The occupation of individuals is also an important factor affecting e-commerce use. Skilled agricultural/forestry/ aquaculture workers and the workers in elementary occupations are less likely to use e-commerce than unemployed individuals. It was determined that the possibility of using e-commerce was higher in other occupational groups compared to unemployed individuals. In a study, it was detected that employed individuals were more inclined to use e-commerce compared to the unemployed [55]. In another study, it was reported that employees, self-employed individuals constituted the occupational group who mostly preferred e-commerce, followed by students, retired, other inactive and unemployed groups [22].

In the study, it was determined that the expected possibility of using e-commerce increased as the income increased. It is indicated that income positively affects online shopping. In the studies in the literature, it was determined that the increase in income increased the possibility of online shopping $[56,57,55,58]$. In a study in which it was stated that the effects on consumer behaviors often occurred between external and internal factors, it was reported that the improvement of socioeconomic conditions, one of external factors, had a significant effect on e-commerce use [59]. In another study in which the factors affecting e-commerce motivation were investigated, it was stated that the fact that individuals living in Greece especially paid attention to pricing and promotion sensitivity in their online shopping was affected by income level and economic conditions [60].

The region of residence also affects online shopping. While those who mostly preferred online shopping were living in TR1 (İstanbul) and TR2/TR4 (West/East Marmara) region, those who least preferred it were living in TRC (Southeastern Anatolia) region. As a result of a study conducted with Thai online shoppers, it was observed that consumers did face-toface shopping instead of online shopping because they found the products they desired in the areas where the population was relatively more intense [52].

Finally, the size of households that do online shopping is also an effective variable. It was determined that the possibility of using e-commerce decreased as household size increased. In a study, it was stated that the number of children was negative, small but insignificant in online shopping [48]. In another study, it was determined that the number of children had no effect on online shopping. In a study, contrary to that study, it was determined that the number of children had a positive effect on online shopping [50].

According to the results obtained in the study, it was determined that the year of survey, education and income level increased the possibility of online shopping. It was determined that age, household size and being a woman decreased the possibility of online shopping. One of the interesting results of the study was that the individuals residing in the TRC (Gaziantep, Adıyaman, Kilis, Şanlıurfa, Diyarbakır, Mardin, Batman, Şırnak, Siirt) region were less likely to do online shopping compared to the TRA/TRB (Erzurum, Erzincan, Bayburt, Ağrı, Kars, Iğdır, Ardahan, Malatya, Elazığ, Bingöl, Tunceli, Van, Muş, Bitlis, Hakkâri) region, which is a relatively less developed region. Another remarkable result was that skilled agricultural, forestry and aquaculture workers and the workers in elementary occupations were less likely to do online shopping compared to the unemployed.

The results of the study indicated that e-commerce use was gradually increasing. It was determined that more educated and young individuals and individuals living in relatively more developed regions were more inclined to online shopping. Policies should also be developed to increase e-commerce use of low educated individuals and individuals over middle age. In particular, small and medium-sized businesses (SMB) should pay more attention to the use of e-commerce in order to increase their activities by taking these situations into consideration. Indeed, how important e-commerce use is has been found out in epidemics/pandemics such as COVID-19, which causes people to lock themselves at home in the countries.

Considering that e-commerce has become increasingly widespread and the transaction volume has increased, it can be said that studies to raise awareness of service providers and service recipients are important for adaptation to the digitalization process. As a result of the results, since it was observed that age, gender, educational level, average monthly income and the number of households were effective on online shopping, it is considered that it would be beneficial for service providers to develop advertising and marketing strategies based on this data. Moreover, the requests and complaints of the user can be received directly with real-time field studies in order to detect the preferred factors (price, promotion, time saving, diversity, comparability, change, return options etc.). Thus, competitive advantage can be offered for service providers, and a customizable shopping experience can be offered for users.

This study had some limitations. The dependent variable (status of e-commerce use) discussed this study was not obtained as a result of any commercial registration. The procedure was performed completely considering the responses of the participants. Therefore, the answers may be biased. The variables required for statistical analysis were the variables included in the Information and Communication Technology (ICT) Usage Survey in Households microdata set. However, the variables such as marital status, race, use of social media, use of mobile/internet banking, may affect individuals' online shopping, could not be taken into account.

\section{ACKNOWLEDGMENT}

The authors would like to thank the Turkish Statistical Institute for the data. The views and opinions expressed in this manuscript are those of the authors only and do not necessarily represent the views, official policy, or position of the Turkish Statistical Institute.

\section{REFERENCES}

[1] Barnes, S. J., \& Vidgen, R. T. (2002). An integrative approach to the assessment of e-commerce quality. Journal of Electronic Commerce Research, 3(3), 114-127.

[2] Corbitt, B. J., Thanasankit, T., \& Yi, H. (2003). Trust and e-commerce: a study of consumer perceptions. Electronic commerce research and applications, 2(3), 203-215.

[3] Zwass, V. (2003). Electronic commerce and organizational innovation: Aspects and opportunities. International Journal of Electronic Commerce, 7(3), 7-37. 
[4] Y Monsuwé, T. P., Dellaert, B. G., \& De Ruyter, K. (2004). What drives consumers to shop online? A literature review. International journal of service industry management, 15(1), 102-121.

[5] Jiradilok, T., Malisuwan, S., Madan, N., \& Sivaraks, J. (2014). The impact of customer satisfaction on online purchasing: A case study analysis in Thailand. Journal of Economics, Business and Management, 2(1), 5-11.

[6] Bourlakis, M., Papagiannidis, S., \& Fox, H. (2008). E-consumer behaviour: Past, present and future trajectories of an evolving retail revolution. International Journal of E-Business Research, 4(3), 64-76.

[7] Yu, T.-K., \& Wu, G.-S. (2007). Determinants of internet shopping behavior: An application of reasoned behaviour theory. International Journal of Management, 24(4), 744-762,823.

[8] Onyusheva, I., \& Thongaim, J. (2018). Customer satisfaction in online shopping: A case study of Bangkok urban area. The EUrASEANs: journal on global socio-economic dynamics, 2(9), 13-23.

[9] Jiang, L. A., Yang, Z., \& Jun, M. (2013). Measuring consumer perceptions of online shopping convenience. Journal of Service Management, 24(2), 191-214.

[10] Czaplewski, M. (2017). The use of e-commerce in the promotion and sale of hand made products. Management, 22(1), 154-162.

[11] Zhang, X. (2019). Investigation of e - commerce in China in a geographical perspective. Growth and Change, 50(3), 1062-1084.

[12] Lee, R. J., Sener, I. N., Mokhtarian, P. L., \& Handy, S. L. (2017). Relationships between the online and in-store shopping frequency of Davis, California residents. Transportation Research Part A: Policy and Practice, 100, 40-52.

[13] Changchit, C., Cutshall, R., Lonkani, R., Pholwan, K., \& Pongwiritthon, R. (2019). Determinants of online shopping influencing thai consumer's buying choices. Journal of Internet Commerce, 18(1), 1-23.

[14] Stoklosa, M. (2020). Prices and cross-border cigarette purchases in the EU: Evidence from demand modelling. Tobacco control, 29(1), 55-60.

[15] Valarezo, Á., Pérez-Amaral, T., Garín-Muñoz, T., García, I. H., \& López, R. (2018). Drivers and barriers to cross-border e-commerce: Evidence from Spanish individual behavior. Telecommunications Policy, 42(6), 464-473.

[16] Afsar, B., Qureshi, J. A., Rehman, A., \& Bangash, R. U. (2011). Consumer panacea over internet usage in Pakistan. Management \& Marketing Journal, 9(1), 43-52.

[17] Shin, D.-H., \& Biocca, F. (2017). Explicating user behavior toward multi-screen adoption and diffusion. Internet research, 27(2), 338-361.

[18] Hong, W., Tam, K. Y., \& Yim, C. K. B. (2016). E-service environment: Impacts of web interface characteristics on consumers' online shopping behavior. In R. T. Rust, \& P. K. Kannan (Eds.), E-Service: New directions in theory and practice (pp. 120-140): Routledge.

[19] Park, J., Chung, H., \& Yoo, W. S. (2009). Is the Internet a primary source for consumer information search?: Group comparison for channel choices. Journal of Retailing and Consumer Services, 16(2), 92-99.

[20] Erickson, J., \& Najberg, A. (2015). Cross-border e-commerce to reach $\$ 1$ trillion in 2020. https://www.alizila.com/cross-border-e-commerceto-reach-1-trillion-in-2020/. Accessed 28.03.2020.

[21] EcommerceFoundation (2019). 2018 Global Ecommerce Report. https://www.ecommercefoundation.org/free-reports. Accessed 23.01.2020.

[22] Eurostatstatistics (2018). E-commerce statistics for individuals. https://ec.europa.eu/eurostat/statistics-explained/index.php?title=Ecommerce_statistics_for_individuals\#Context. Accessed 28.03.2020.

[23] Lin, G. T., \& Sun, C. C. (2009). Factors influencing satisfaction and loyalty in online shopping: an integrated model. Online information review, 33(3), 458-475.

[24] Padmavathy, C., Swapana, M., \& Paul, J. (2019). Online second-hand shopping motivation-Conceptualization, scale development, and validation. Journal of Retailing and Consumer Services, 51, 19-32.

[25] Shin, J. I., Chung, K. H., Oh, J. S., \& Lee, C. W. (2013). The effect of site quality on repurchase intention in Internet shopping through mediating variables: The case of university students in South Korea. International Journal of Information Management, 33(3), 453-463.
[26] Kim, J., \& Lennon, S. J. (2013). Effects of reputation and website quality on online consumers' emotion, perceived risk and purchase intention. Journal of Research in Interactive Marketing, 7(1), 33-56.

[27] Wolfinbarger, M., \& Gilly, M. C. (2001). Shopping online for freedom, control, and fun. California management review, 43(2), 34-55.

[28] Park, E. J., Kim, E. Y., Funches, V. M., \& Foxx, W. (2012). Apparel product attributes, web browsing, and e-impulse buying on shopping websites. Journal of business research, 65(11), 1583-1589.

[29] Hamidizadeh, M. R., Haji, K. A. A., \& Naeiji, M. J. (2011). Designing and explaining the model of persistent customer loyalty in e-commerce: A study in the e-retailer's web sites. New Marketing Research Journal, 1(2), 79-92.

[30] Rahman, M. A., Islam, M. A., Esha, B. H., Sultana, N., \& Chakravorty, S. (2018). Consumer buying behavior towards online shopping: An empirical study on Dhaka city, Bangladesh. Cogent Business \& Management, 5(1), 1514940.

[31] Nagar, K. (2016). Drivers of E-store patronage intentions: Choice overload, internet shopping anxiety, and impulse purchase tendency. Journal of Internet Commerce, 15(2), 97-124.

[32] TÜiK (2018). Hanehalkı Bilişim Teknolojileri/ICT Usage Survey in Households. http://www.tuik.gov.tr/MicroVeri/HBT_2018/english/index.html. Accessed 03.04.2020.

[33] Alkan, Ö., Oktay, E., \& Genç, A. (2015). Determination of factors affecting the children's internet use. American International Journal of Contemporary Research, 5(6), 57-67.

[34] Bilenkisi, F., Gungor, M. S., \& Tapsin, G. (2015). The impact of household heads' education levels on the poverty risk: The evidence from Turkey. Educational Sciences: Theory and Practice, 15(2), 337348.

[35] Alkan, Ö., \& Abar, H. (2020). Determination of factors influencing tobacco consumption in Turkey using categorical data analyses1. Archives of environmental \& occupational health, 75(1), 27-35.

[36] Alqahtani, A. S., Goodwin, R. D., \& de Vries, D. B. (2018). Cultural factors influencing e-commerce usability in Saudi Arabia. International Journal of Advanced and Applied Sciences, 5(6), 1-10.

[37] Law, M., \& Ng, M. (2016). Age and gender differences: Understanding mature online users with the online purchase intention model. Journal of Global Scholars of Marketing Science, 26(3), 248-269.

[38] Teo, T. S. (2006). To buy or not to buy online: adopters and nonadopters of online shopping in Singapore. Behaviour \& Information Technology, 25(6), 497-509.

[39] Constantinides, E. (2004). Influencing the online consumer's behavior: the Web experience. Internet research, 14 (2 ), 111-126.

[40] Al-Jahwari, N. S., Khan, F. R., Al Kalbani, G. K., \& Al Khansouri, S. (2018). Factors influencing customer satisfaction of online shopping in Oman: Youth perspective. Humanities \& Social Science Reviews, 6(2), 64-73.

[41] Niu, H. J. (2013). Cyber peers' influence for adolescent consumer in decision - making styles and online purchasing behavior. Journal of Applied Social Psychology, 43(6), 1228-1237.

[42] Hill, W. W., \& Beatty, S. E. (2011). A model of adolescents' online consumer self-efficacy (OCSE). Journal of business research, 64(10), 1025-1033.

[43] San, L. Y., Omar, A., \& Thurasamy, R. (2015). Online purchase: a study of generation $\mathrm{Y}$ in Malaysia. International Journal of Business and Management, 10(6), 1-7.

[44] Doherty, N. F., \& Ellis - Chadwick, F. E. (2003). The relationship between retailers' targeting and e - commerce strategies: an empirical analysis. Internet research, 13(3), 170-182.

[45] Hashim, A., Ghani, E. K., \& Said, J. (2009). Does consumers' demographic profile influence online shopping?: An examination using Fishbein's theory. Canadian Social Science, 5(6), 19-31.

[46] Escobar-Rodríguez, T., Grávalos-Gastaminza, M. A., \& Pérez-Calañas, C. (2017). Facebook and the intention of purchasing tourism products: moderating effects of gender, age and marital status. Scandinavian Journal of Hospitality and Tourism, 17(2), 129-144. 
[47] Lee, S. L., Ibrahim, M. F., \& Hsueh-Shan, C. (2005). Shopping-centre attributes affecting male shopping behaviour. Journal of Retail \& Leisure Property, 4(4), 324-340.

[48] Stranahan, H., \& Kosiel, D. (2007). E - tail spending patterns and the importance of online store familiarity. Internet research, 17(4), 421-434.

[49] Koyuncu, C., \& Lien, D. (2003). E-commerce and consumer's purchasing behaviour. Applied Economics, 35(6), 721-726.

[50] Leong, L.-Y., Jaafar, N. I., \& Ainin, S. (2018). Understanding facebook commerce (F-commerce) actual purchase from an artificial neural network perspective. Journal of Electronic Commerce Research, 19(1), 75-103.

[51] Bellman, S., Lohse, G. L., \& Johnson, E. J. (1999). Predictors of online buying behavior, association for computing machinery. Communications of the ACM, 42(12), 32-38.

[52] Palvia, P. (2009). The role of trust in e-commerce relational exchange: A unified model. Information \& management, 46(4), 213-220.

[53] Aghdaie, S. F. A., Piraman, A., \& Fathi, S. (2011). An analysis of factors affecting the consumer's attitude of trust and their impact on internet purchasing behavior. International Journal of Business and Social Science, 2(23).
[54] Fernández, A. M. G. (2000). Los valores personales en el comportamiento del consumidor: Revisión de diversas metodologías aplicadas al marketing. Esic Market(107), 9-36.

[55] Vicente, M. (2015). Determinants of C2C e-commerce: an empirical analysis of the use of online auction websites among Europeans. Applied Economics Letters, 22(12), 978-981.

[56] Burkolter, D., \& Kluge, A. (2011). Online consumer behavior and its relationship with socio-demographics, shopping orientations, need for emotion, and fashion leadership. Journal of Business and Media Psychology, 2(2), 20-28.

[57] Cristóbal-Fransi, E., Martín-Fuentes, E., \& Daries-Ramon, N. (2015). Behavioural analysis of subjects interacting with information technology: categorising the behaviour of e-consumers. International Journal of Services Technology and Management, 21(1-3), 163-182.

[58] Akhter, S. H. (2003). Digital divide and purchase intention: Why demographic psychology matters. Journal of Economic Psychology, 24(3), 321-327.

[59] Kumar, V., \& Dange, U. (2012). A study of factors affecting online buying behavior: A conceptual model. SSRN Electronic Journal.

[60] Rohm, A. J., \& Swaminathan, V. (2004). A typology of online shoppers based on shopping motivations. Journal of business research, 57(7), 748757. 